\title{
Professionals calling in lifelong learning centers
}

\author{
Victor Seco, Miguel Pereira Lopes \\ Social and Political Sciences Institute - Tech Univ Lisbon (Portugal) \\ victor.seco@gmail.com,.mplopes@iscsp.utl.pt
}

Received: July 2012

Accepted: November 2012

\section{Abstract:}

Purpose: This study aims to understand how the way people see their work and the authentizotic character of their organizational climate contribute to the building of a Great Place to Work.

Design/methodology/approach: This paper presents the results of a quantitative investigation that correlate the perceptions of organizational climate and the work orientations of professionals with different occupations on Portuguese lifelong education centers.

Findings: The study indicates that all the core elements of an authentizotic organization contribute to explain what people potentially expect from their companies: adequate material conditions plus a meaningful contribution.

Practical implications: The study has implications in the future for National Qualification Agency directors, education politicians and human resource managers who are responsible for providing good expectations within a healthy context of talent retention.

Originality/value: The novel contribution of this paper is the finding that employee's work orientations and authentizotic climate are related to each other in a Lifelong learning Center in the public education sector.

Keywords: work orientation, authentizotic organizational climates, great places to work, lifelong learning 
..."Other orientations toward work certainly exist; work can be experienced as an alienating grind, an opportunity for challenge and growth, or any number of other framings. But callings have stolen center stage in our imaginations as offering some sort of special gateway to fulfillment and meaning in work."

Wrzesniewski (2011)

\section{Introduction}

Since the beginning of the 1970's we have witnessed the emergence of a new educational paradigm. Differing significantly from the traditional one, which was based on "preparing for life", adopted by adults who try to instill society's principles and values in children and adolescents, since this paradigm is essentially on a lifelong scale. A special interaction has been created between education and each member of the community. As in Blue Mountain, studied by Giles and Hargreaves (2006: page. 136-150) "the school established the idea of being a "learning community" as the core of its mission." Then the andragogy construct, elaborated by Knowles (1984, 1990), and explained later by Brown (2006) "as the art and science to help others to learn", appears to help governments and politicians to decide a better future for all.

On the other side of the bench the quality of life related to those within the educational process is crucial in order to develop countries and civilizations as there are many professionals in the world who develop lifelong learning processes. Those persons need to be engaged in doing their job, because working with adults and their problems is not easy and entails more than merely a salary in return for their work. It is far more than simply a wellpaid job and a structured career, working in a lifelong learning center requires a special kind of dedication and a humanitarian predilection towards caring for people. When employees feel that the organization cares for and is helpful to the whole community, they feel that they are performing meaningful work. As Kets de Vries (2001: page 107) argues, "meaningful activity at work becomes a way to transcend personal concerns; it becomes a way to create a sense of continuity. Leaving behind a legacy through work becomes an affirmation of the person's sense of self and identity; it can become an important form of narcissistic gratification." Meaningful work fosters the employees' self-esteem, hope, health, happiness and sense of personal growth (Csikszentmihalyi, 2003; Kets de Vries, 2001).

As such, in the current study it is very important to stress Calling as the Portuguese New Opportunities Centers (NOCs) most perceived work orientation. As meaningful places to work, along with professionals touched by calling and in addition to their authentizotic climate facets, they become "great places to work", thus defining NOCs as nontoxic places to work. The NOCs organizational structure, an innovative group in Portuguese public administration, includes clear political and operational levels so misunderstandings or interferences between "workers" and managers are reduced. In public schools in particular, the NOCs represent a new 
leadership formula. Those who work in low structural/technical levels are directly responsible for the success of their own work and that is reflected directly in the NOCs fixed goals.

Given this, the present paper aims to elucidate on the importance of the work orientation Calling, its structure, content and the very essence of the construction of special and great places to work. To achieve this goal we explore correlations between perceived work orientations, authentizotic climates and the occupations of the professionals. This paper is structured as follows. After explaining what work orientation is and which components the construct is comprised of, we will explore the concept of "Best places to work" and the relationship with the "authentizotic organizations" construct to capture their climatic characteristics and the essence of these vibrant and meaningful workplaces. Next, we will develop some political, physical and professional observations concerning the occupations performed by the respondents. We will then follow the usual format: method, results, discussion and conclusions. The main limitations of the research and suggestions for future research are also explored.

\subsection{Work orientation}

Employees increase their commitment and quality of life due to satisfaction with work (Loscoco \& Roschelle, 1991, Wrzesniewski, McCauley, Rozin \& Schwartz, 1997). People who consider their work as a Job live simply to earn money, as that allows them to do whatever they wish to do outside of their job. They have little investment and gain little satisfaction other than the paycheck. As Wrzesniewski et al. (1997: page 22) said, "The major interests and ambitions of Job holders are not expressed through their work". When work is perceived as a job, people look forward to taking a break, finishing work, the weekend, public holidays, and vacations. Outside of their working hours, little or no thought, time, or energy is devoted to the work. On the other hand, people who believe that the most important thing in their life is their Career place importance not only on the money they can possibly earn, but also on their ability to climb to the upper realms of power or make decisions within their organization. A career is perceived as a progression of continuous improvement through pay raises, promotions, better opportunities and experiences regarded as essential to ongoing advancement. People commit themselves to working far beyond the normal workday, during evenings, weekends, and vacations. As such, they "have a deeper personal investment in their work and mark their achievements" (Wrzesniewski et al., 1997: page 22).

Coetzee (2008) presents a valuable theoretical framework (career enablers, career drivers, career harmonisers, career preferences and career values) to help individuals recognise the significance of developing their inner career resources and drawing on these psychological resources to improve their universal employability characteristics and abilities. Last but not least, we refer to Calling as the way people live to work. Their work is something that simply fulfills their lives. They are unconcerned with earnings or career advancements. A calling is 
work that a person feels called to do by a higher power. Work that is a calling feels like it both contributes to humanity and is also in line with an individual's purpose in life. Characteristically, people perceiving their work as a calling indicate they would do the work for little or no pay, so satisfying is it. For those individuals, it is the work itself which provides satisfaction, rather than any external recognition or reward. People "find that their work is inseparable from their life" (Wrzesniewski et al., 1997: page 22). Dobrow (2004) proposes a new calling construct, comprised of seven elements: 1) passion; 2) identity; 3) need to do it/urgency; 4) longevity; 5) engulfs consciousness; 6) sense of meaning; 7) self-esteem. The author presupposes that having a calling could be measured, and its background and consequences (behavioral, cognitive, and affective) could be explored.

\subsection{Best places to work}

The "Best places to work" project started in the United States less than 30 years ago (Levering \& Moskowitz, 1983). The purpose was to select and announce the names of organizations with good practices towards their employees. The design of the project belongs to the Great Place to Work Institute, located in San Francisco, which surveys American and, more recently, European, Latin American and Asian workplaces, giving employees the opportunity to evaluate their company regarding its philosophy, policies and practices. Every year, since 1998, Fortune magazine has published the names of the "100 best workplaces to work" (e.g., Levering \& Moskowitz, 1998; Moskowitz \& Levering, 2003). The evaluation model includes five dimensions: credibility, respect, fairness, pride and camaraderie. The model represents the commonly accepted expression of a focus on the human side of the organization, and is also present in projects all over the world. The "best places to work" model received the support of the European Commission (European Commission, 2001), which also set it up as a way to disseminate best practices of human resource management in the European Union and as a way to promote corporate social responsibility (Rego \& Cunha, 2005: page 4).

\subsection{Authentizotic organizations}

The "great places to work" concept is related to the authentizotic organizations construct referred to by Kets de Vries (2001). In books such as "Coach and Couch" and "The Leader on the Couch", Kets de Vries suggests that organizations should be, what he calls, 'authentizotic.' Based on the Greek words authenteekos ('authentic') and zoteekos ('vital to life'), he says these are organizations in which "you really feel alive" and are a "flag to show these are the best companies to work for." An in-depth analysis of these companies reveals that they are steeped in human values, such as trust, fun, candor, empowerment, and respect for the individual, fairness, teamwork, customer orientation, accountability, continuous learning, and openness to change. These companies are also distinguished as being family friendly. These characteristics go a long way toward explaining the success of many of Fortune's forward thinking organizations. After carrying out exploratory and confirmatory factor analyses on a 
measure of the six authentizotic dimensions, Rego and Souto (2004a, 2004b) and Rego and Cunha (2005) came to a six-factor model: spirit of camaraderie; credibility of the leader; open and frank communication with the leader; opportunities for learning and personal development; fairness/equity; work-family conciliation. The model fits the data well, reliabilities are satisfactory, and the six climate types predict significant variance of intent to leave, organizational commitment and individual performance (Rego, 2004; Rego \& Souto, 2004a, 2004b; Rego \& Cunha, 2005). These findings are important because they suggest that an exemplary workplace reduces staff turnover, and promotes organizational commitment, individual performance and organizational effectiveness. These dimensions are crucial for the understanding of work orientation, especially if we test how the occupation performed correlates with that relationship and we could find evidence of healthy organizations to work in. Based on the aforementioned research findings and the specific characteristics of those Lifelong Learning organizations (NOCs - New Opportunities Centers), the following hypothesis was formulated:

H1: Perceived facets of authentizotic climates are significantly related to work orientation.

H2: Occupations performed are significantly related to perceived facets of authentizotic climates.

H3: Occupations performed are significantly related to work orientation.

\section{Method}

\subsection{Sample}

The participants were a convenience sample of employed adults at managerial and staff levels in a Portuguese governmental Lifelong Learning initiative. They came from different northern Portuguese locations. Of the 168 respondents, 75\% were female, with a mean age of 34.1 years (age range 20-59). This sample included individuals in a range of occupations related to NOCs, including directors, coordinators, diagnosis and "pathfinder" counselors, recognizing and validating competences counselors, trainers, external evaluators and administrative technicians, distributed as we can see in Table 1 . We have chosen a special type of Lifelong Learning organization found in Portugal: The New Opportunities Centers (NOCs). These organizations are generally composed of young people, who are extremely intrinsically motivated and who have a high level of training. In 2000, a National System of Recognition, Validation and Certification of Competences (RVCC) was created in Portugal resulting from the principles stated in the Memorandum on Lifelong Learning, European Commission (2000) and the so-called Lisbon Strategy (2000, 2005 and 2008). NOCs were created with the main goal of implementing this system, so that adults could be qualified with a diploma of either basic education level or of secondary education level. In order to put this into context it seems relevant to clarify that NOCs are officially defined in legal documents as gateways for Lifelong Learning. On arrival at a New 
Opportunities Center, adults are interviewed and then go through a so-called diagnosis step, devised to make them aware of their competencies and the knowledge acquired throughout their lives (lifelong and life wide). It seems relevant to mention that each NOC has a technicalpedagogical team which is composed of: the NOC director, who represents the center; the pedagogical coordinator, who is responsible for pedagogical, technical and evaluation supervision; the diagnosis and "pathfinder" counselor, who gives the adult advice on the best pathway to achieve qualifications according to his/her character and life experience; the recognizing and validating competences counselors, who counsel and guide the adults and coach the adults through the RVCC process; the trainers of the different Key Competences Areas of the Key Competences Frames of Reference for Adult Education and Training (basic and upper secondary levels), who help the adult to interpret reference frameworks and validate their competences and the administrative technician, who develops administrative work and provides front-office service. There is also an independent element who does not form part of the technical-pedagogical team but is crucial to the social recognition of the system: the external evaluator. All of the members of the NOI (New Opportunities Initiative) are paid either through European funds or by the Portuguese Government (ANQ report to Confintea, 2008). Both private and public NOCs have a similar organizational system and similar goals. The major differences relate to the financial budget, leadership practices and human resources management. NOCs represent a new level of leadership in Portuguese public administration. In $2010,43 \%$ of NOCs were based in lower secondary and upper secondary state schools. They are effectively micro organizations inside a bigger one. Locally ruled by the school directors they have centrally delegated autonomy given by the National Qualifications Agency (NQA). A Quality Chart has been designed as a guideline for the NOCs activity, namely action paths and procedures, which establishes national targets for adult qualifications and the three performance levels to be obtained by each NOC in order to contribute to the country's targets. A national IT appliance (SIGO) was also created to store, manage and supply information on the outcomes of the NOI. Therefore NOCs seem to represent new challenges for schools through implementing a new type of educational provision bringing them closer to the local community and through enabling them to become a kind of lifelong learning and educational services supplier. This has already led to organizational changes in schools. In each case, a part of the main building or premises has been allocated to the center, its staff and the adults who are enrolled in the process of recognizing, validating and certifying competences. Members of the school teaching staff have already been allocated a specific type of work required by the center. Partnerships with local companies and businesses have been established, so that their workers could begin the process of improving their qualifications. The center's team meets the adults at their workplaces or villages as this is a more convenient setting for them. Other issues are the work and tasks performed by teachers. The teacher who will be in charge of the coordination of the center has to project a certain image, have leadership and teamwork skills and be available to embrace this new full time task because he or she will be the key person in the development of the NOCs activity and of the pedagogical and "curricular" team. The teachers who work in the center as 
trainers deal with new work and tasks: they are asked to uncover and validate competences based on a Key Competences Frame of Reference. Even teachers can take on the role of counselors having responsibility for recognizing and validating competences. In former times there were teachers who volunteered to work in an NOC because they saw it as a challenge, something new in the Portuguese educational and training system related to adult education, something which was worth trying. Now, that could prove to be a weighty obligation owing to teacher unemployment and while some people may consider that this kind of provision offered by the school is not part of the teaching profession but in fact a different job, others consider this kind of work as a despicable job (Cotrim, 2010). Therefore, this seems to be an adequate context in which to study career orientations. As we have said this sample included individuals in a range of occupations related to NOCs, including directors, coordinators, diagnosis and "pathfinder" counsellors, recognizing and validating competences counselors, trainers, external evaluators and administrative technicians, illustrated as we can see in the following table.

\begin{tabular}{|l|r|r|r|}
\hline & Frequency & \multicolumn{1}{|c|}{ Percent } & \multicolumn{1}{c|}{$\begin{array}{c}\text { Cumulative } \\
\text { Percent }\end{array}$} \\
\hline Director & 9 & 5,4 & 5,4 \\
\hline Coordinator & 21 & 12,5 & 17,9 \\
\hline Trainer & 52 & 31,0 & 48,8 \\
\hline Diagnosis & 15 & 8,9 & 57,7 \\
\hline RVCC & 60 & 35,7 & 93,5 \\
\hline A.Technicians & 5 & 3,0 & 96,4 \\
\hline E.Evaluators & 6 & 3,6 & 100,0 \\
\hline Total & 168 & 100,0 & \\
\hline
\end{tabular}

Table 1 . NOCs range of occupations, frequencies and percentages

\subsection{Comparative analysis}

We have decided, in order to enable cross-referencing with other data, to group distinct occupations into four dimensions of authentizotic climates of decision or participation in the RVCC process: directors and coordinators (political decisions), trainers (school participation), diagnosis and RVCC professionals (core workers) and lastly administrative technicians and external evaluators (out-sourcing the process). We present data similar to the study by Rego and Cunha (2005), regarding the dimensions of authentizotic climates, and to the study by Wrzesniewski et al (1997), concerning the way in which people regard their work.

\subsection{Procedure}

During a professional convention, we initiated our investigation by collecting data through a questionnaire, which required individuals to report their perceptions of organizational climate and work orientations. 


\subsection{Measures}

Authentizotic dimensions. Studies conducted by (Rego, 2004; Rego \& Souto, 2004a, 2004b; Rego \& Cunha, 2005; Souto \& Rego, 2003) confirmed the reliability and validity of the questionnaire in both Portuguese and Brazilian contexts. It is comprised of 21 six-point selfreport scales, measuring the six authentizotic dimensions described above. A six-point scale ranging from "the statement is completely false" to "the statement is completely true". Table 2 provides examples of the issues associated with each dimension.

\begin{tabular}{|c|c|}
\hline Spirit of Camaraderie & $\begin{array}{l}\text { There is a great team spirit. } \\
\text { There is a sense of family between the employees. }\end{array}$ \\
\hline $\begin{array}{l}\text { Trust and credibility of the } \\
\text { leaders }\end{array}$ & $\begin{array}{l}\text { Leaders fulfill their promises. } \\
\text { People trust their leaders. }\end{array}$ \\
\hline $\begin{array}{l}\text { Open and frank communication } \\
\text { with the leader }\end{array}$ & $\begin{array}{l}\text { People feel free to communicate frankly and openly with the leaders. } \\
\text { It is easy to talk with people placed at higher positions in the organization. }\end{array}$ \\
\hline $\begin{array}{l}\text { Opportunities for learning and } \\
\text { personal development }\end{array}$ & $\begin{array}{l}\text { People feel that important responsibilities are assigned to them. } \\
\text { People feel that they can develop their potential. }\end{array}$ \\
\hline Equity/fairness & $\begin{array}{l}\text { When good outcomes are reached through the employees' efforts, the "laurels" } \\
\text { (e.g., compensation and praise) are distributed only to a few managers. ( } r \text { ) } \\
\text { There is personal favoritism in the promotions. ( } r \text { ) }\end{array}$ \\
\hline Work-family conciliation & $\begin{array}{l}\text { To advance in the career, it is necessary to sacrifice the familiar life. ( } r \text { ) } \\
\text { This organization helps employees to reconcile work and family life. } \\
\text { The organization creates conditions so that people can keep up the children's } \\
\text { instruction. }\end{array}$ \\
\hline
\end{tabular}

(r) means inversed item Adapted from Rego and Cunha (2005)

Table 2. Authentizotic dimensions issues

Exploratory factor analysis, after varimax rotation. We have found five factors similar to those of Souto and Rego (2003) and similar data is in Table 3. The factors worked on by Rego and Cunha (2005) at a later date are presented in the left-hand column.

The findings extracted from the factorial scheme reveal to us that most of the internal consistency items are above 0,54 except inversed items with negative values. The question 8 , also a negatively charged item, presents a positive value which could be related with some misunderstood by professionals. In fact, working with people without qualifications is hard. The "laurels", namely compensation and praise, are not the same as in other businesses. So far it is clear that, the most powerful explanation dimensions are: Spirit of Camaraderie and Respectful Behavior from the leader (namely, Trust and credibility of the leader and also Open and frank communication with the leader), which could mean, in our opinion, a great deal of "complicity" in the local political managers and the followers relationships. 


\begin{tabular}{|c|c|c|c|c|c|}
\hline & $\begin{array}{l}\text { Factor } 1 \\
(0,77)\end{array}$ & $\begin{array}{l}\text { Factor } 2 \\
(\mathbf{0 . 8 9 )}\end{array}$ & $\begin{array}{c}\text { Factor } 3 \\
(0.67)\end{array}$ & $\begin{array}{c}\text { Factor } 4 \\
(-0.31)\end{array}$ & $\begin{array}{c}\text { Factor } 5 \\
(0,72)\end{array}$ \\
\hline There is a great team spirit. & 0.864 & & & & \\
\hline There is a sense of family between the employees. & 0.773 & & & & \\
\hline People show concerns for the well-being of the others. & 0.628 & & & & \\
\hline The organization atmosphere is friendly. & 0.445 & & & & \\
\hline Leaders fulfill their promises. & & 0.680 & & & \\
\hline People trust in their leaders. & & 0.698 & & & \\
\hline People feel that the leaders are honest. & & 0.743 & & & \\
\hline $\begin{array}{l}\text { People feel free to communicate frankly and openly with } \\
\text { the leaders. }\end{array}$ & & 0.770 & & & \\
\hline People feel free to show discordances to their leaders. & & 0.797 & & & \\
\hline $\begin{array}{l}\text { It is easy to talk with people placed at higher positions in } \\
\text { the organization. }\end{array}$ & & 0.710 & & & \\
\hline $\begin{array}{l}\text { People feel that important responsibilities are assigned to } \\
\text { them. }\end{array}$ & & & 0.622 & & \\
\hline $\begin{array}{l}\text { People can place their creativity and imagination in benefit } \\
\text { of the work and the organization. }\end{array}$ & & & 0.543 & & \\
\hline People feel that they can learn continuously. & & & 0.732 & & \\
\hline People feel that they can develop their potential. & & & 0.630 & & \\
\hline $\begin{array}{l}\text { When good outcomes are reached through the employee's } \\
\text { efforts, the "laurels" (e.g., compensation and praise) are } \\
\text { distributed only to a few managers.( } r \text { ) }\end{array}$ & & & & 0,547 & \\
\hline There is personal favoritism in the promotions.( $r)$ & & & & $-0,826$ & \\
\hline People feel discriminated.(r) & & & & $-0,880$ & \\
\hline $\begin{array}{l}\text { To advance in the career, it is necessary to sacrifice the } \\
\text { familiar life.( } r \text { ) }\end{array}$ & & & & & $-0,698$ \\
\hline $\begin{array}{l}\text { This organization helps employees to reconcile work and } \\
\text { family life's. }\end{array}$ & & & & & 0,666 \\
\hline $\begin{array}{l}\text { The organization acts in order to allow people can } \\
\text { conciliate work with their familiar responsibilities. }\end{array}$ & & & & & 0,681 \\
\hline $\begin{array}{l}\text { The organization creates conditions so that people can } \\
\text { keep up the children's instruction. }\end{array}$ & & & & & 0,743 \\
\hline
\end{tabular}

Kaiser-Meyer-Olkin Measure $=0,88(0,91)$; Bartlett's Test of Sphericity $=1786,63(2604,99)[p=0,0000]$

(r) means inversed item

Table 3. Authentizotic organizational dimensions. Exploratory factor analysis 
Confirmatory factor analysis. The means, standard-deviations and standardized regression weights $(\lambda)$ for authentizotic characteristics are presented in Table 4 and Figure 1.

\begin{tabular}{|c|c|c|c|}
\hline $\begin{array}{l}\text { Dimensions of } \\
\text { authentizotic climate }\end{array}$ & Means & $\begin{array}{l}\text { Standard } \\
\text { deviations }\end{array}$ & $\begin{array}{c}\text { Standardized Regression } \\
\text { Weights }(\boldsymbol{\Lambda})\end{array}$ \\
\hline Spirit of camaraderie & 4,42 & 0,934 & \\
\hline Question 3 & 4,68 & 1,180 & 0,68 \\
\hline Question 12 & 4,14 & 1,165 & 0,66 \\
\hline Question 15 & 4,35 & 1,083 & 0,78 \\
\hline Question 19 & 4,63 & 1,075 & 0,60 \\
\hline Trust and credibility of the leader & 4,40 & 0,994 & \\
\hline Question 6 & 4,35 & 1,204 & 0,60 \\
\hline Question 16 & 4,36 & 1,035 & 0,76 \\
\hline Question 20 & 4,57 & 1,092 & 0,91 \\
\hline Open and frank communication with the leader & 4,41 & 1,106 & \\
\hline Question 7 & 4,31 & 1,243 & 0,79 \\
\hline Question 17 & 4,43 & 1,151 & 0,96 \\
\hline Question 18 & 4,55 & 1,172 & 0,72 \\
\hline Opportunities for learning and personal development & 4,57 & 0,836 & \\
\hline Question 1 & 4,68 & 1,170 & 0,33 \\
\hline Question 4 & 4,70 & 1,054 & 0,47 \\
\hline Question 10 & 4,61 & 0,922 & 0,74 \\
\hline Question 21 & 4,39 & 1,111 & 0,84 \\
\hline Fairness/Equity & 3,12 & 0,896 & \\
\hline Question 8 & 3,77 & 1,574 & 0,63 \\
\hline Question 13 & 2,96 & 1,732 & $-0,82$ \\
\hline Question 14 & 2,68 & 1,617 & $-0,78$ \\
\hline Work-family conciliation & 3,70 & 1,008 & \\
\hline Question 2 & 2,64 & 1,356 & 0,26 \\
\hline Question 5 & 4,11 & 1,345 & 0,69 \\
\hline Question 9 & 4,15 & 1,279 & 0,90 \\
\hline Question 11 & 3,99 & 1,252 & 0,66 \\
\hline $\begin{array}{l}\text { Adjustment index } \\
\text { Complete standardized solution }\end{array}$ & \multicolumn{3}{|c|}{$\begin{array}{c}\mathrm{X} 2(\backslash \mathrm{df})=325,927 ; \mathrm{p}=, 000 ; \times 2 / \mathrm{df}=1,873 \\
\mathrm{CFI}=, 909 ; \mathrm{PCFI}=, 753 ; \mathrm{GFI}=, 851 ; \mathrm{PGFI}=, 641 \\
\mathrm{RMSEA}=, 072 ; \mathrm{P}(\mathrm{rmsea}<=0,05)=, 002\end{array}$} \\
\hline
\end{tabular}

Table 4. Authentizotic organizational dimensions. Confirmatory factor analysis

We must point out the most powerful results $(\geq 0,75)$ on confirmatory analysis:

Questions 20, 16 and 17, highlight two special traits of Portuguese NOCs, the perceived honesty and frank communication of the leader. There is a perception of a respected and frank relationship between leaders and followers; Question 15 shows the perception of the NOCs' spirit of camaraderie, which is related to work connections, levels of performance and common professional purposes; Question 21 reflects the NOCs' employees' perception of opportunities for their potential development; Questions 13 and 14 show the NOCs' members' perception of equity; finally Question 9 suggests, that professionals perceive that NOC organizations act in order to enable people to balance work with their family responsibilities. 


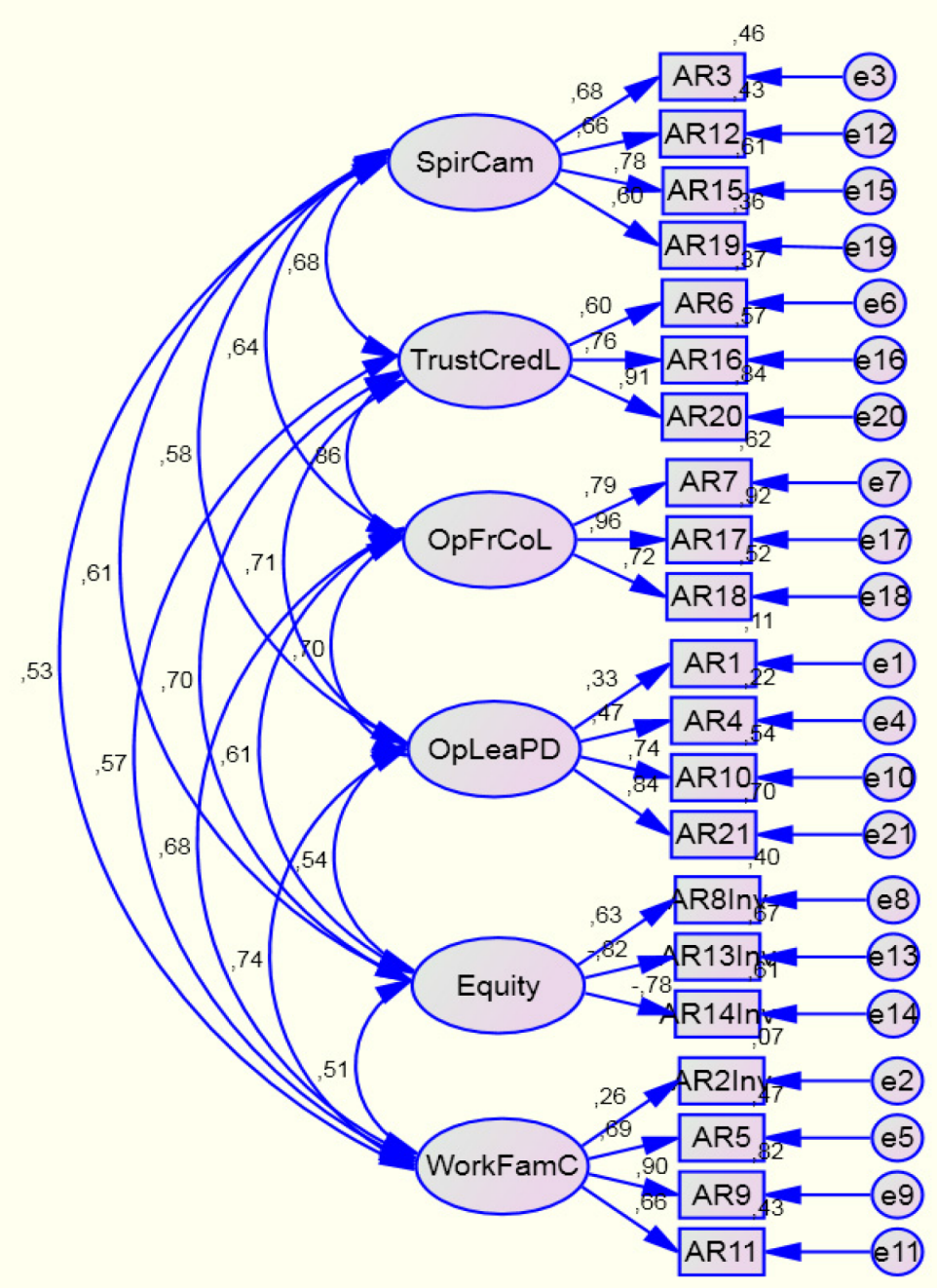

Figure 1. Confirmatory factor analysis. Authentizotic dimensions

Work orientations. We have used a translated adaptation of the "University of Pennsylvania WORK-LIFE questionnaire" used by Wrzesniewski et al (1997). We have translated the 18 items into Portuguese asking about specific aspects of relationships at work ignoring the authors' true-false proposition. A five-point Likert-type scale was used for the subjects' responses to each of the 18 items. Table 5 shows some examples of the issues associated with each relationship.

\begin{tabular}{|l|l|}
\hline \multirow{2}{*}{ Job } & $\begin{array}{l}\text { I am very conscious of what day of the work week it is and I greatly anticipate } \\
\text { weekends. I say, "Thank God it's Friday!" } \\
\text { I am eager to retire. }\end{array}$ \\
\hline Career & $\begin{array}{l}\text { I expect to be in a higher level job in five years. } \\
\text { I feel in control of my work life. }\end{array}$ \\
\hline Calling & $\begin{array}{l}\text { My work makes the world a better place. } \\
\text { I tend to take my work with me on vacations. }\end{array}$ \\
\hline
\end{tabular}

Table 5. Work orientations issues

Assuming that "the job-career-calling distinction is not necessarily dependent upon occupation" (Wrzesniewski et al, 1997), our aim was to observe whether the three distinct ways people 
regard their work are available in our sample. We grouped the questions according to Wrzesniewski's perception of each dimension. A five-point scale is used ranging from "strongly disagree" to "strongly agree".

The exploratory factorial analysis results show Cronbach's work dimensions alphas are 0,482 for Job, $-0,205$ for Career and 0,534 for Calling.

Cronbach's alpha value of Career dimension is negative, due to a negative average covariance among items that defy the assumptions of the reliability model, and so this dimension failed. We have also tried to improve our study regarding the other two work orientations. So we have eliminated items number 2 and 15 on the reliability analysis of the Job dimension and number 5 on the Calling dimension. Then we obtained better Cronbach's alphas of 0,517 for Job and 0,609 for Calling respectively. We conclude that this instrument was psychometrically acceptable despite constraints.

\section{Results}

The relationship between the variables was calculated by means of Pearson's correlations. This method allowed the researcher to identify the direction and strength of the relationship between each of the variables. As shown in Table 6, significantly positive and negative relationships were observed between occupations and authentizotic climate dimensions, job and calling work orientations.

\begin{tabular}{|c|c|c|c|}
\hline & Job & Calling & Occupation \\
\hline Spirit of camaraderie & $-0,065$ & $0,161^{*}$ & $-0,182 *$ \\
\hline Trust and credibility of the leader & $-0,112$ & $0,289 * *$ & $-0,210 * *$ \\
\hline Open and frank communication with the leader & $-0,157 *$ & $0,298 * *$ & $-0,246 * *$ \\
\hline $\begin{array}{l}\text { Opportunities for learning and personal } \\
\text { development }\end{array}$ & $-0,267 * *$ & $0,257 * *$ & $-0,294 * *$ \\
\hline Fairness/Equity & 0,044 & $-0,098$ & 0,118 \\
\hline Work-family conciliation & $-0,010$ & $0,245 * *$ & $-0,150$ \\
\hline Occupation & $0,202 * *$ & $-0,156^{*}$ & - \\
\hline
\end{tabular}

Table 6. Pearson's correlations

The significant correlations range from $r=-0,294$ to $0,298(p \leq 0,01)$ and from $r=-0,182$ to $0,161$ ( $p \leq 0,05)$. Table 6 shows a significant positive relationship between the climate dimensions and calling. Calling has significant positive Pearson correlations with every climate dimension [from $r=0,245$ to $0,298(p \leq 0,01)$ ], with the exception of equity. Job has only two $[r=-0,157(p \leq 0,05)$ and $r=-0,267(p \leq 0,01)]$ significant negative correlations with climate dimensions. Based on the statistical results, $\mathrm{H} 1$ (perceived facets of authentizotic climates are 
significantly related to work orientations) is only partially accepted with calling work orientation. Table 6 shows that every climate dimension has a significant $(0,01$ level) negative Pearson correlation with occupation performed, excepting equity. As we have put occupations in the following order [directors and coordinators (political decisions $=11$ ), trainers (school participation $=12$ ), diagnosis and RVCC professionals (core workers $=13$ ) and, in last place, administrative technicians and external evaluators (out-sourcing the process $=14$ )] we could conclude that the facets of authentizotic climates are more perceptible for people placed on lower levels of decision-making. Focusing on the statistical results, $\mathrm{H} 2$ (occupations performed are significantly related to perceived facets of authentizotic climates) is totally accepted. Table 6 present Calling as having a significant negative Pearson Correlation $(r=-0,156, p \leq 0,05)$ with occupation performed. At the same time Job has a significant Pearson correlation $(r=0,202, p \leq 0,01)$ with occupation performed. The contradiction between Job and Calling correlations shows that people who have opposed work orientations assume a contradictory relationship with the occupation performed. People who consider Calling as an important work orientation have no political or formal power on the NOCs structure. This means that H3 (occupations performed are significantly related to work orientations) is almost totally accepted because we haven't consider Career work orientation.

\section{Discussion}

The study explored the relationship between occupation performed in relation to the authentizotic climate dimensions and work orientations, both together and separately. There seems to be a need for research on how the perceived psychological facets of authentizotic climates enhance individuals' calling and job orientations in the construction of a great place to work. Although not all of the research hypotheses were accepted, our results indicated a number of significant relationships between the variables which provided valuable pointers about the relationship between the variables of concern to the present study. The following socio-demographic characteristics of the sample were kept in mind when interpreting the data: the participants were predominantly employed and were mainly women in their early adulthood life/career stages, mostly occupying middle level staff positions in the field of RVCC training and education.

Overall, the results suggest that participants who value the spirit of camaraderie in their occupation are also connected to the calling orientation. The closely related term vocation has been defined as a calling to something larger than oneself (Greenbalt \& Greenbalt, 2001), such as an over-whelming desire to find meaning in our lives through work (Fine, 2003). Dobrow (2007) found that among musicians, perceptions of calling were related to the level of involvement in musical activities, enjoyment of practicing, having parents involved in the arts, and enjoyment of socializing with other musicians, but not to their level of ability or demographic variables. Collectively, results from these studies suggest that adults who view their career as a calling appear to have higher levels of well-being, work satisfaction, 
enjoyment of their work, and occupational commitment. There is a transcendental dimension of work partnership, beyond work itself, referred to the whole meaning of the work. In addition, the significant relationship observed between occupation performed, calling work orientation and the work-family balance values, suggests that participants who value conciliation between all that, deserve to improve their employability characteristics and abilities, not forgetting their highly enthusiastic contribution to the organization. These findings are in agreement with those of Coetzee and Esterhuizen (2010). The authors found that if people were clear about their career goals, they would be more optimistic and emotionally balanced. Moreover, as observed by Meyer and Allen (1997), having the possibility to influence the goals of the organization seems to increase the participants' sense of responsibility towards continuing to work for the organization. It appears that open and frank communication with the leader plus opportunities for learning and personal development, both related to occupation performed, tend to increase a sense of accountability in relation to their contribution towards making the organization a Great Place to Work. Kidd (2008) found too that having positive thoughts and clarity about the future relates to positive career experiences or feelings. In addition, our findings also suggest that having good climate perceptions would contribute to the strongest work orientation, namely Calling. These findings are in agreement with those of Meyer, Allen and Smith (1993), who suggest that affective commitment develops when involvement in one's occupation proves to be a satisfying experience (for example being given the opportunity to do satisfying work or to develop valued skills). Finally we can adjoin the importance of the special contribution of middle level staff positions people on the achieving of great places to work at CNOs. We conclude that people who feel that their work place makes the difference on society greater good are people who thought less on career or money implications. They do the things for the others sake because they assume it is the best way.

The novel contribution of this paper is the application of work orientation and authentizotic climates scales, generally used on private enterprises investigations, to the public education sector, in particular the Lifelong Learning.

\section{Conclusion}

The findings of this study could have implications for NQA directors, education politicians and human resource managers who are responsible for providing good expectations within a healthy context of talent retention. As Rego \& Cunha (2005) said, "if managers aim to build healthy and effective organizations, they may want need to pay attention to a number of aspects: (a) their ethical, honest, respectful and trustful way of acting; (b) the opportunities for learning and personal development that they provide to employees; (c) the degree to which they take employees as people in search of meaningful work and a positive sense for life; (d) the honesty and frankness they place in communicating with subordinates; (e) the ways they allow their subordinates to strike a balance between work and family; ( $f$ ) the ways they 
promote a spirit of camaraderie and teamwork; $(\mathrm{g})$ the fairness that they express in their decisions, namely those involving promotions and rewards." Coetzee and Bergh (2009) note that career behaviors and career meta-skills may lead to higher levels of life and career satisfaction and, as indicated by the results of the present study, through people's emotional attachment to the organization. Perhaps in this way there will emerge a true sense of calling. Dobrow (2004) claimed that a calling can be considered as an extreme form of subjective career success. It is wise not to forget Hirschi (2010), who says that sense of calling in one's career is supposed to have positive implications for both individuals and organizations but current theoretical development is plagued with incongruous conceptualizations of what does or does not constitute a calling. Despite its contributions, this study has several limitations. The main limitation is that the work orientations results, mostly the career dimension ones, were not in line with the studies which initially inspired us. Another limitation could be related to the lower lambdas of some correlations. This research approach would require a larger sample, in order to find clusters of a significant size and which were more statistically comparable. Despite these criticisms, the study indicates that all core elements of authentizotic organizations may widely contribute to management theory and practice in educational institutions by clarifying what people potentially expect from their companies: adequate material conditions plus a meaningful contribution. With this paper, we present some evidence of authentizotic climates in special organizations of LifeLong Learning. We also prove that the work and tasks performed are significantly related to those climates. Finally we conclude that there are some NOCs with authentizotic climates and they are great places to work. Given the lack of empirical evidence and the limitations in terms of instruments of measurement, we hope that our work will stimulate more researchers to study other kind of authentizotic, public and private, organizations.

\section{References}

Brown, K. (2006). Leadership for Social Justice and Equity: Evaluating a Transformative Framework and Andragogy. Educational Administration Quarterly, 42(5) December, 700-745. http://dx.doi.org/10.1177/0013161X06290650

Coetzee, M. (2008). Psychological career resources of working adults: A South African survey. SA Journal of Industrial Psychology, 34(2), 32-41.

Coetzee, M., \& Bergh, Z.C. (2009). Psychological career resources and subjective work experiences of working adults: An exploratory study. SA Business Review, 13(2), 1-31.

Coetzee, M., \& Esterhuizen, K. (2010). Psychological career resources as predictors of African graduates' coping resources: An exploratory study. Manuscript submitted for publication.

Cotrim, A. (2010), The Impact of New Opportunities Centers (NOC) on school organization and on teachers' work, Lisbon University, Institute of Education. 
Csikszentmihaly, M. (2003). Good business: Leadership, flow and the making of meaning. New York: Viking.

Dobrow, S.R. (2004). Extreme subjective career success: A new integrated view of having a calling. Paper presented at the Annual Meeting of the Academy of Management, New Orleans, LA.

Dobrow, S.R. (2007). The development of calling: A longitudinal study of musicians. Best Paper Proceedings of the Academy of Management Conference, Philadelphia.

European Commission (2000). Commission Memorandum of 30 October 2000 on lifelong learning [SEC(2000) 1832 final - Not published in the Official Journal].

European Commission (2001). Promoting an European tramework for corporate social responsibility. Luxembourg: European Communities.

Fine, R.M. (2003). Career spirituality-Learning the R.O.P.E.S. (ERIC Document Reproduction Service No. ED480523).

Giles, C., \& Hargreaves, A. (2006). The Sustainability of Innovative Schools as Learning Organizations and Professional Learning Communities During Standardized Reform. Educational Administration Quarterly, 42(1), 124-156. http://dx.doi.org/10.1177/0013161X05278189

Greenbalt, A., \& Greenbalt, P. (2001). Integrating psychology and spirituality during career exploration. Paper presented at the National Career Development Association Global Conference, Vancouver, BC, Canada.

Levering, R., \& Moskowitz, M (1983). The 100 Best Companies to Work for in America. New York: Doubleday.

Levering, R., \& Moskowitz, M. (1998). The 100 best companies to work for in America. Fortune, January 12, 26-35.

Loscocco, K. A., \& Roschelle, A. R. (1991). Influences on the quality of work and nonwork life: Two decades in review. Journal of Vocational Behavior, 39, 182-225. http://dx.doi.org/10.1016/0001-8791(91)90009-B

Hirschi, A. (2010). Callings in career: A typological approach to essential and optional components. Journal of Vocational Behavior, article in press.

Kets De Vries, M.F.R. (2001). Creating authentizotic organizations: Well-functioning individuals in vibrant companies. Human Relations, 54(1), 101-111. 
Kidd, J.M. (2008). Exploring components of career well-being and the emotions associated with significant career experiences. Journal of Career Development, 35(2), 166-186. http://dx.doi.org/10.1177/0894845308325647

Knowles, M. et al (1984) Andragogy in Action. Applying modern principles of adult education. San Francisco: Jossey Bass. A collection of chapters examining different aspects of Knowles' formulation.

Knowles, M.S. (1990) The Adult Learner. A neglected species (4e), Houston: Gulf Publishing. First appeared in 1973. 292 + VIII pages. Surveys learning theory, andragogy and human resource development (HRD).

Meyer, J.P., \& Allen, N. (1997). Commitment in the workplace, theory, research and application. California: Sage.

Meyer, J.P., Allen, N.J., \& Smith, C.A. (1993). Commitment to organisations and occupations: Extension and test of a three-component conceptualization. Journal of Applied Psychology, 78(4), 538-551. http://dx.doi.org/10.1037/0021-9010.78.4.538

Moskowitz, M., \& Levering, R. (2003). 10 great companies to work for in Europe. Fortune, January 20, 26-38.

Rego, A. (2004). Organizações autentizóticas: Desenvolvimento e validação de um instrumento de medida. Estudos de Gestão. Portuguese Journal of Management Studies, IX(1), 53-76.

Rego, A., \& Souto, S. (2004a). Comprometimento organizacional em organizações autentizóticas. Revista de Administração de Empresas, 44(3), 30-43.

Rego, A., \& Souto, S. (2004b). La relación entre los climas organizacionales autentizóticos y las variables intención de salida de la organización, el compromiso organizacional y el estrés. Revista Lationoamericana de Administración, 32, 77-101.

Rego, A., \& Cunha, M.P. (2005). Authentizotic organizing and employee happiness: an empirical study. Working Papers in Management, G/n07/ 2005. Universidade de Aveiro.

Souto, S., \& Rego, A. (2003). Organizaciones autentizóticas: Un estudio de validación del constructo en Brasil. Alcance - Administração, 10 (3), 394-418.

The development and state of the art of Adult Learning and Education (ALE) (2008). National report of Portugal at CONFINTEA by Agência Nacional para a Qualificação (National Qualifications Agency).

Wrzesniewski, A., McCauley, C., Rozin, P., \& Schwartz, B. (1997). Jobs, Careers, and Callings: Peoples's Relations to their work. Journal of Research in Personality, 31(1) March, 21-33. http://dx.doi.org/10.1006/jrpe.1997.2162 
Wrzesniewski, A. (2011). "Callings". The Oxford Handbook of Positive Organizational Scholarship. Cameron, K., \& Spreitzer G. (Eds.). Oxford University Press. Pp 45-54.

Journal of Industrial Engineering and Management, 2013 (www.jiem.org)

Article's contents are provided on a Attribution-Non Commercial 3.0 Creative commons license. Readers are allowed to copy, distribute and communicate article's contents, provided the author's and Journal of Industrial Engineering and Management's names are included. It must not be used for commercial purposes. To see the complete license contents, please visit http://creativecommons.org/licenses/by-nc/3.0/. 